\title{
The language(s) of Love: JRB Love and contesting tongues at Ernabella Mission Station, 1940-46
}

\author{
David Trudinger
}

In a recent collection of essays, Umberto Eco, the well-known author and professor of semiotics, suggests the idea of translation as a complex process of negotiation, between texts, authors, readers, languages and cultural frameworks, with the translator as negotiator. ${ }^{1}$ Extending this already expansive and productive notion to translation as any interaction between two languages, and translator as anyone involved intimately in that process, I want to examine the role of missionaries - in particular that of the Reverend JRB Love ${ }^{2}$ - in 'negotiating' the relative place of the colonising language, English, and an Indigenous language, Pitjantjatjara, in the life of an A boriginal mission station, Ernabella, in Central Australia in the early 1940 s. $^{3}$ Lest there be any confusion, Love was also a 'translator' in the narrower sense, being involved at the mission in the conversion of part of the biblical text to the Indigenous language. This is an instructive story in itself that this article can only touch on, but I am more interested here in examining his rolein, and his rationale for, advocating and attempting to negotiate a bilingual language policy at the mission siteagainst an opposing vernacular-only policy.

The maintenance of indigenous languages in the face of powerful onslaughts from dominant culture languages has been a part of the narratives of both colonialism and postcolonialism. ${ }^{4}$ In Australia, debates have continued on the advisability or otherwise of the retention of Indigenous languages, given the dominance of English, with arguments often moving on to intricate questions of the survival and autonomy of minority cultures. ${ }^{5}$ An earlier form of these debates occurred at Ernabella, which had been established in 1937 along what has been seen by historians as liberal and progressive lines. ${ }^{6}$ The mission was founded by Dr Charles Duguid, a leading Adelaide surgeon, Presby-

\footnotetext{
1. Eco 2003: 6, 34.

2. James Robert Beattie Love, 1889-1947.

3. Pitjantjatjara was regarded by the early missionaries at Ernabella as the main local variant or dialect of what has become known as the Western Desert Language. Yankunytjatjara, a related dialect, would al so have been spoken by some Indigenous people at the mission.

4. See, for example, Phillipson 1992; Young 2001; Coates 2004.

5. See, for example, Harker and McConnochie 1985; Gale 1992; McKay 1996; Report of the Select Committee 2004.

6. Broome 1994: 117-118; Harris 1990: 856-857; Hilliard 1976.
} 
terian elder and activist for the A boriginal cause. ${ }^{7}$ An underlying rationale for the welfare, biomedical and educative 'model' of the new mission was the well-documented failure in Australia of many 19th-century mission ventures which had 'imposed Christ', and European civilisation, on 'the natives'. ${ }^{8}$ Missionaries at Ernabella were now to try to 'understand the culture' and respect it: a policy of relative non-interference with Indigenous culture and customs was envisaged. The local language, Pitjantjatjara, thus becamea core part of Duguid's program for Ernabella: the missionaries were to learn to speak it as the means to a sympathetic, respectful perspective on Indigenous culture; it was to be the lingua franca on the mission site; and, importantly, schooling was to be conducted in Pitjantjatjara, not English.

How did this Duguidian vision transfer to the complex 'contact zone' of the mission? ${ }^{9}$ We begin with the lie of theland. Ernabella Creek, a karu, ran between the mission compound and the Indigenous camps. In an earlier work, I envisaged the karu as a metaphor for the liminal space where the encounter between Pitjantjatjara and European took place. ${ }^{10}$ Here, the metaphor merges real and symbolic, as the creek bed was in fact the locale for the 'first' school class at Ernabella, in February 1940. There is a photograph of this event. A dozen naked black children sit attentively in two rows at rough-hewn desks. They are facing a small blackboard perched on a large rectangular wooden structure, attended by what looks like a small boy. The far side of the karu is lined with spindly trees. The young white schoolteacher, RM Trudinger, my father, is not in the picture ${ }^{11}$ Probably he is taking the photograph. Later, after the school becomes seen in missionary circles as the jewel in the Ernabella crown, this representation of the meeting in the karu takes on the status of an originary event: the first halting words of the 'long conversation' between the Pitjantjatjara and these European intruders. ${ }^{12}$

Well, perhaps not quite 'the first words'. In 1937, prior to the establishment of the mission, the Presbyterian missionary, the Reverend JRB Love, then superintendent of theWestern Australian mission at Kunmunya, had conducted two preparatory visits to Ernabella, during which hesketched out a rudimentary grammar and vocabulary. Love had a high reputation in his church as a linguist, anthropologist and scholar: an exemplary missionary. He had translated part of the Bible into the Worora language of the Kimberley, completed a MA in linguistics at Adelaide University and had written a book which articulated a new, progressive missiology of 'enlightened gradualism', 'grafting' Christianity onto affinitive spiritual beliefs and customs of 'stone-age savages'. ${ }^{13}$ Love had also developed an intricate theory of duty owed to the Indigenous

7. Charles Duguid, 1884-1986.

8. Duguid 1936: 98-105. While Ernabella never becamethe medical mission (with a resident doctor) Duguid had originally envisaged and promoted, from early on it had a nursing presence and a hospital-dispensary.

9. Pratt 1992: 6-7.

10. Trudinger 2004.

11. Ronald Martin Trudinger, 1918-2002.

12. In fact, small classes had been held at Ernabella before the teacher's arrival but these were conducted in English by the first superintendent's wife, and have been largely ignored in the Ernabella iconography. For 'the long conversation', see Comaroff and Comaroff 1991 for their use of this notion in representing the encounter of European missionaries and the Tswana in Southern Africa.

13. Love 1936. See al so Biskup 1973: 127. 
people of A ustralia. Dispossession ('we are living on their land'), although followed by many 'wrongs', had been justified since A borigines had not developed the land. But this right to take the land, since exercised without payment, was conditional on an obligation to take responsibility for the dispossessed, as a partial act or gesture of recompense and reparation. ${ }^{14}$

So Love, a man imbued with a heavy sense of duty, offered his services while on furlough from Kunmunya in 1937 to assist Duguid and the Presbyterian Board of Missions with setting up the mission at Ernabella. The Ernabella that met Love then was a Ionely white outpost in the far north-west of South Australia, with a few sheep, goats, horses and camels. It had been a base for 'doggers' selling dingo scalps, procured on the cheap from A borigines, to the Government. ${ }^{15}$ Love had told HC Matthews, the Secretary of the Board of Missions, that he wished 'to do something useful with this year ... put the grammar of the local people on a written basis, for the use of future missionaries'. ${ }^{16}$ He worked hard to grasp the language, with the help of the local inhabitants: leaving Ernabella on a camel trip, 'three little boys ran alongside us, pointing out objects to us, and naming them till late afternoon' ${ }^{17}$ He reported to Matthews regularly: 'Making tolerable progress with the language - the men are interested and eager to hel $p$ me.' ${ }^{18}$ Love kept his notebook at the ready but it was not easy: at a camp he 'tried for more words, but there was so much chattering that I did not make much headway'. ${ }^{19}$ Slowly things improved, 'wider connections' were made, and Love was able to leave the first superintendent 'some notes on the native language'. 20

Thenew Mission began in November 1937, with Rev. Harry Taylor as its head. For our purposes, the next two significant events in its narrative were the arrival of the first teacher in early 1940, and the return of Love himself as superintendent in March 1941. We have al ready glimpsed the 'first class' in the karu. Trudinger quickly picked up the language. By A pril 1940, he was revising and adding to Love's grammar 'notes'. Already there was an edge to the critique of the older man's work: 'it seems the syntax forms are more complicated than [Love] imagined. ${ }^{21} \mathrm{He}$ described to Duguid the first classes in the creek, with 'desks made out of old kerosene boxes' and the children 'practicing letters with charcoal on their tummies'. Then a crucial claim: 'I conduct school in their language. ${ }^{\prime 22}$ The policy of teaching in Pitjantjatjara was to be adhered to fiercely by the teacher, supported by Duguid and the Board. But there were early signs of problems after Love had arrived as superintendent in 1941. The teacher wrote confidentially to the Board advising that as Love had not requested a report on the school for the Annual Report he would to send it directly to the Board. Healso argued vehemently for closure of the school during a period of his possible absence: any 'imposition' of English while

14. Love 1922.

15. Hilliard 1976: 81-83.

16. Love to Matthews, 16July 1937, Presbyterian Church of Australia (hereafter PCA), ML MSS 1893/ Folder 4/ 1937.

17. 5June 1937, Series 21, Papers of JRB Love.

18. Love to Matthews, 24 August 1937, PCA, ML MSS 1893/4/ 1937.

19. 30 August 1937, Series 21, Papers of JRB Love.

20. Love to Matthews, 13 N ovember 1937, PCA, ML MSS 1893/4/ 1937.

21. Trudinger to Matthews, 30 A pril 1940, PCA, ML MSS 1893/ 1/ 1939-46.

22. Trudinger to Duguid, 5 A pril 1940, PCA, ML MSS 1893/ 1/ 1939-46. 
he was away, he feared, would be 'definitely harmful' and create 'tragic confusion'. He argued that the whole basis of the 'gradual introduction' of the native children to 'our culture' was that it was being done with 'the vernacular as the medium' ${ }^{23}$

Was this policy a vernacular-only one? Duguid himself suggested much later that it had been the plan to introduce English 'as a foreign language' after three years, but there is little evidence that this was the understanding of the missionaries at Ernabella in the early 1940 s. $^{24} \mathrm{H}$ istorically, missionaries in Australia had worked, in the main unsuccessfully, along the more traditional missiological lines of seeking spiritual conversions among 'natives', often to the exclusion of any serious interaction with Indigenous culture and language. ${ }^{25}$ At Ernabella, the evangelical Trudinger had become convinced that the conversion project was best facilitated by a translation of Christian concepts, doctrine, narrative into Indigenous forms, whether text, songs (hymns), or art. His primary object at Ernabella was eventually to have translations of the Bible - initially a Gospel or two - available for each family, in which there was at least one person educated to read in Pitjantjatjara. ${ }^{26}$ On the other hand, neither Duguid nor Love could be said to reside in the evangelical wing of the Presbyterian Church. ${ }^{27}$

Duguid's primary and immediate motivation at Ernabella was humanitarian and biomedical, to save bodies, rather than souls. He also saw a link between saving the Indigenous language and preserving the Indigenous culture. Indigenous retention of language would build pride in culture. On language, then, his position aligned with Trudinger's, although their motivations and rationales were different. Love's position on language and culture was more complex. He had been a notable pioneer of A ustralian efforts to translate oral Indigenous languages to a written form and the colonial Biblical text into an Indigenous one. ${ }^{28} \mathrm{He}$ also believed strongly that indigenes should hear and read the Word of God in their own language. But Love was also a proponent of the view that A borigines needed to be provided with English as an essential tool to negotiate the inevitable culture clash between what he saw as a 'primitive' people against a more advanced civilisation. JRB Love had always seen the destinies of white and black in Australia as being inextricably entwined. Almost 30 years before, he had written to his friend John Flynn: 'The question of white and back are wholly bound up in each other. We cannot deal with one apart from the other. ${ }^{29}$ And so he began to

23. Trudinger to Matthews, 10 August 1941, PCA, ML MSS 1893/ 1/ 1939-46. Duguid 1978: 27.

25. Broome 1994: 101-119. See al so H arris 1990 who gives credit to some of the honourable exceptions to this generalisation: Lancelot Threlkeld, Carl Strehlow, JG Reuther, and Love himself, at Kunmunya.

26. Matthews to Love, 25 Sep 1943, PCA, ML MSS 1893/ 4/ 1943, with Matthews putting Trudinger's position as one with which the Board was in 'general agreement'.

27. Duguid's autobiography, as well as his papers and correspondence, show little evidence of a strong evangelical faith, that is, a strong personal belief in conversion, godliness, and mission: see Carey 1996: 10-19. There is very littlemention of God, let alone Christ (Duguid 1972). Love, as a practising missionary, ostensibly 'preaching Christ to the savages', as he put it, is a little harder to place. He may have considered himself evangelical in a broad sense. I place him in a more progressive, moderate wing of his church as he does not appear to display the rather single-minded concentration on the conversion project, the task of saving souls above all else, which tends to identify the 'true' evangelical (see Trudinger 2004). 
resist, slowly, subtly, and stubbornly, the vernacular-only language policies dictated by Duguid's vision and implemented, equally stubbornly, on the mission site by the young schoolteacher.

Education was the principal arena where this conflict was played out. The schooling of native children had always been an important priority for missions, and particularly Presbyterian missions which, historically, had placed education on an equal level with evangelisation as missionary objectives. ${ }^{30}$ The Board and Duguid saw the Ernabella School even from its early days as the crowning achievement of the Mission. ${ }^{31}$ The reasons for this are clear: the methodologies of education at the school aligned perfectly with the broad policies of the Duguidian enterprise: all the teaching, and learning, was in the local language, the children were encouraged to remain uncl othed, live with their families and participate in the cultural life of the tribe, including walkabout and initiation. In the schoolteacher's words:

They speak and are taught little or no English; all instruction is given in their own language and subjects are correlated as far as possible with native and natural life. They are encouraged to go away daily and hunt in the bush, that is, to be fully learned in their natural school with vital subjects as bush lore, keenness of observation, swiftness of limb. ${ }^{32}$

This view of the school was reinforced by the South Australian Education Department, which subsidised the salary of the teacher and attested to the school's 'unique and exceptional' qualities. ${ }^{33}$ The praise that was constantly lavished on the school did not sit easily with Love. He saw the schooling at Ernabella as not dissimilar to the methods used at Kunmunya, with the difference that in the Kimberley mission, attention was also paid to teaching English. His first comment upon the school on arrival as superintendent in 1941 perhaps reflected his ambivalence: 'The little school is away over beyond the goat and ram yards, and is rather out of thelife of the mission. This is a defect, but has its good points, when a lot of children are shouting. ${ }^{34}$

It appears that part of the context of the language policy divisions on the Ernabella mission site were differences over the relative significance of the conversion project. To Trudinger, raised in an intensely evangelical and missionary-minded family, 35 'our chief aim' was, as he noted to Matthews, for the children 'to know of a God and Saviour and then know Him for their own'. ${ }^{36}$ In a talk reprinted in the mission newsletter in 1943, the school teacher gave an explicitly evangelical justification for the native language policy: 'we aim to make these uncivilized nomadic people as universally literate

29. Love to Flynn, 9 February 1914, Flynn Papers, National Library of A ustralia (hereafter NLA), MS 3288, Box 3, Folder 2.

30. Stanley 2001.

31. See, for example, Matthews to Trudinger, 18June 1941, PCA, ML MSS 1893/ 1/ 1939-46; Duguid to Matthews (copy), 23 July 1941, Papers of Charles Duguid.

32. Ernabella newsletter, with article by Dr C Fenner, Director of SA Education Department, quoting RM Trudinger, StateRecords of SouthA ustralian (hereafter SRSA), GRG 52/ 1/ 1941/ 22.

33. Fenner, quoting RM Trudinger, SRSA, GRG 52/ 1/ 1941/ 22.

34. Love to Matthews, 13 March 1941, PCA, ML MSS 1893/ 4/ 1941.

35. His father (my grandfather), a medical missionary with the Sudan Inland Mission in A frica, was one of 13 siblings in a family of German origin. All except one became missionaries.

36. Trudinger to Matthews, 17 July 1942, PCA, ML MSS 1893/ 1/ 1939-46. 
as possible [so] that when the scriptures are translated and can be circulated amongst them, they will be able to use them to the fullest advantage ... [even] on their WalkAbouts. ${ }^{37}$ Earlier he had expressed the same thought when advising Matthews in March 1943 that there were now about 40 children who could read and write in their own language: 'soon every family can have at least one member who can read and write against the time when the Scriptures are circulated'. 38

Nonetheless, like Duguid and Love, the evangelical schoolteacher at Ernabella was also thinking of the integrity of the 'tribe', the Pitjantjatjara: 'We simply must find a way by which we can bring these people... Christ's message of life, and at the same time maintain the physical and social and tribal life of the tribe.' Trudinger added, in a newsletter of 1943: 'To us it seems wrong and un-Christlike that missionaries should purport to bring the so-called life more abundant, and be the conscious or unconscious perpetrators of physical death.' 39 So the evangelical was also concerned about physical 'salvation', of the body as well as the soul. But 'sin' seemed al ways at the heart of the evangelical discourse: 'the great need', he noted in a private circular to 'the friends of Ernabella', 'is a Holy Spirit conviction of sin'. While devoted to the children, he lamented that, with them, 'there is no consciousness of doing wrong, no sense of falling short of God's glory. No conscience seems to exist with regard to lying and thieving. 40 Salvation from sin, Christian redemption was always the principal priority, the fundamental need.

Love rarely wrote privately or publicly in such terms. The first sentence of his 1944 'Policy for Ernabella' read: 'Our Scriptural Commission is to heal the sick and preach the Gospel. ${ }^{41}$ Even here, the priority was given to the physical over the spiritual salvation. $\mathrm{H}$ is second sentence was also characteristic: 'To this has been added the special duty of trying to preserve the race from extinction.' It was in the pursuance of this 'special duty' that he saw the importance of English - thelanguage of the dominant and superior culture as he saw it - for the Aborigines. He also took an elevated view of 'time' in relation to the conversion project, in contrast to the evangelical urgency of saving souls. In 1944, in commenting on the time away from the mission for A boriginal boys under initiation, Love remarked that:

their years of adolescence are under the charge of their tribal elders rather than of the missionaries. I think we must acquiesce, for some years to come, at least, and never seek to break the authority of their elders: but in due time to win the elders, too, to the way of Christ. I think I could work up enthusiasm and have a large number of men and women baptised soon. And what would be the good of that? $^{42}$

JRB Love believed that premature conversion to Christianity, unconnected to elements in Indigenous spiritual life, might hold unforeseeable and troubling conse-

37. Ernabella Newsletter, December 1943, citing Trudinger, SRSA, GRG 52/ 1/ 1943/ 16.

38. Trudinger to Matthews, 3 March 1943, PCA, ML MSS 1893/ 1/ 1939-46.

39. Ernabella Newsletter, December 1943, citing Trudinger, SRSA, GRG 52/ 1/ 1943/ 19.

40. Trudinger to 'Friends', A pril 1942, PCA, ML MSS 1893/ 1/ 1939-46.

41. The Policy of Ernabella (Love 1944), PCA, ML MSS 1893/ // Reports and Policy Statements 1938-45.

42. The Policy of Ernabella (Love 1944), PCA, ML MSS 1893/ 2/ Reports and Policy Statements 1938-45. 
quences for Indigenous identity and culture. In his book about the Worora, he had put forward the thesis that it was not only possible to 'graft' Christianity onto A boriginal spirituality but that this was the only way for the European religion to take effective hold in Indigenous life. ${ }^{43}$ At Ernabella, Love seemed resigned to the view that the fruits of the mission's labours lay well into the future, that the 'long conversation' would continue to take place for generations to come, and in fact would only continue to take place if the present generation was given a future into which to survive. The differences at Ernabella were often a matter of degree. An early missionary from Hermannsburg had once described the Lutheran mission's objective as the 'salvation' of the Aborigine 'in time and in eternity'. ${ }^{44}$ In the case of Ernabella, it was the moderate Love who tended to put a pragmatic missiological emphasis on 'salvation in time' ('to preserve the race from extinction'), while Trudinger emphasised 'eternity', spiritual salvation ('to know a God and a Saviour'). Neither would have disavowed the alternative or opposite objective, but their priorities seemed reflected in their differing emphases on English and the Indigenous language.

In September of 1943, at his request, the Board met with Trudinger in Melbourne to discuss language policy. Subsequently, while reassuring Love somewhat naively that the discussions were conducted 'in complete loyalty to yourself and with a recognition constantly expressed that yours was the final authority on the Mission Station', Matthews advised the superintendent that the Board was in 'general agreement' with the native language policy of the schoolteacher. ${ }^{45}$ This policy was that 'the people be literate in their own language, until such time as a real need is seen to introduce the systematic teaching of English'. The justification of the policy was its trajectory: that at least one person in each family could read in Pitjantjatjara, pending the translation of the scriptures. ${ }^{46}$ The volume of praise being bestowed upon the school and the teacher by the metropolitan audience was clearly irritating Love at this time. He objected to

43. Love 1936.

44. Louis Schulze, cited in Radford 1992: 68.

45. Matthews to Love, 24 September 1943, PCA, ML MSS 1893/4/ 1943. The question of 'loyalty' was becoming a sensitive one. While Love was concerned in 1943 with 'lack of loyalty' on the part of some (unnecessarily unnamed) staff who may not have 'rel ished my taking over command', Matthews assured him, somewhat naively, that 'there has never been theslightest evidence of disloyalty'. I use 'naively' advisedly as my close reading of the Trudinger correspondence with Matthews and the Board of Missions suggests a careful but determined and constant critique of Love's superintendency. It should benoted that Trudinger had asked to meet the Board 'privately', asking that 'no other missionaries [be] present', to put his case for the language policy: Trudinger to Matthews, 29July 1943, PCA, ML MSS 1893/ 1/ 1939-46. Was this 'undermining' the superintendent by going behind his back or was it legitimately 'd efending' the Duguidian language policy of the mission? Whichever it was, it was apparently done, Matthews observed, with a 'constantly expressed recognition' of loyalty to Love and his authority on the mission site. It must be admitted that this so-called 'loyalty' is not evident at all in the correspondence. Trudinger continued to express, privately to Matthews, his dissatisfaction with the administration of the mission and what he characterised as the 'autocratic control' exercised by Love over other missionaries on the mission site. While he disingenuously continued to acknowledge formally his 'fealty' to the superintendent, he made dear privately that his prior loyalties were due 'to God and then to the natives and their cause': see for example Trudinger to Matthews, 1 Mar 1944 and 21 March 1944, PCA, ML MSS 1893/ 1/ 1939-46. 
what he knew was a false claim in an Ernabella newsletter that by teaching native children to write in their own language, the pupils were achieving 'something aboriginals have never done before in any part of Australia'. At Kunmunya, Love asserted to Matthews, 'scholars learned to write in English and Worora'. 47

For his part, the young school teacher privately complained to Matthews that he had become weary of 'reporting' his achievements to Love: 'I'm tired of writing [about] myself on a project of which I am the initiator ... [Love's] annual report has much on sheep yards and dog scalps and makes no mention of the translation work (his or mine) or the issuing of a Hymn Book of thirty Pitjantjatjara hymns, and little reference to the school work.' To Trudinger, the fact that 'seventy children could now read and write in their own tongue' was seen by Love as 'not significant' whereas the superintendent found it important to note that their advancement in English was 'disappointing' . ${ }^{48}$ If it could be said that 'a politics of hospitality' was operating in the larger mission site, it was being displaced by the politics of hostility in the staff room. ${ }^{49}$

Love's response to being told peremptorily of the 'policy of the school' was to pen his own version, 'Ernabella: The Policy of the School' ${ }^{50}$ It was a powerful defence of his position on language at the mission site. He began by saying that after the war, there would be an inevitable increase in the number of white contacts with Ernabella people: 'civilization has come to the people frequenting Ernabella'. Love put the question of language policy firmly in terms of assisting the Pitjantjatjara 'meet the impact of civilization' and the 'land hunger' after the war:

I fear that we may have to fight hard to retain the use of the Musgrave Ranges for the aborigines. Already jealous murmurs are heard, asking why blacks should have this good land. The aborigines will have to prove that they are fit to retain their own land. If we can help them to prove it we shall do them a service. ${ }^{51}$

Love was adamant that Indigenous A ustralians would have to 'earn' their place in the new post-war society, even to keep 'their own land'. Nothing was ever given or taken for free in Love's moral economy. He conceded the value of the vernacular: 'We are all agreed that it is a very valuable thing to teach the children to read and write in their own language; they must have the story of Christ in their own tongue, that they

47. Love to Matthews, 5 October 1943, PCA ML MSS 1893/ 4/ 1943.

48. Trudinger to Matthews, 8 August 1944, PCA, ML MSS 1893/ 1/ 1939-46.

49. I argue in Trudinger 2004 that, following Levinas and Derrida, a complex politics of hospitality operated on the mission site at Ernabel la: the Indigenous people, as hosts of the land, welcomed the missionaries to their land; while missionaries, as hosts of the mission, welcomed the Indigenous peopleacross the karu into the mission compound. However, one is sometimes surprised by the atmosphere of hostility engendered in Christian contact zones, where relationships with the Other in Indigenous form are often appreciably more 'hospitable' than those with the Other in missionary and colleague form! These problems were not new at Ernabella. Before Love arrived at the mission, Walter MacDougall, acting superintendent in 1940, advised Matthews that his suggestion of prayer meetings and Bible study for feuding missionaries was not working as they could not agree on what form the meetings should take! MacDougall concluded: 'I think the best way for the present is to keep them as far away from each other as possible': MacDougall to Matthews, 19June 1940, PCA, ML MSS 1893/ 5/ 1940-46.

50. Love to Matthews, 6 October 1943, PCA, ML MSS 1893/ 4/ 1943.

51. Love to Matthews, 6 October 1943, PCA, ML MSS 1893/ 4/ 1943. 
can repeat and love to recapitulate'. He paid tribute to the work of Trudinger in the school. Yet, to survive, the natives needed more:

without English, I cannot see that the school is justified ... To me it is depressing to see the children of Ernabella so backward in comparison to the children of our other missions. $^{52}$

Love argued that what was needed was the sort of education that would enable the brightest of the 'bright boys here' to 'stand up and personify the best qualities of their race, and to prove by their own example that the aborigine has a right to a place in this land'. However, the superintendent indicated that he did not want to 'enforce my views on this so important matter' and promised Trudinger 'every cordial encouragement from me to continue it the way he has been doing in the school' ${ }^{53}$ Love was attempting to negotiate a bi-lingual policy by offering a large stick of criticism and a small carrot of conciliation.

Love's stern judgment of the school and its native language policy must have cut deeply with his critics, who remained silent for the moment. Matthews, on behalf of the Board, was, however, as diplomatic as ever towards Love, the exemplary missionary, writing to him that his statement had been 'greatly appreciated' by the Board: all, he said, were agreed on 'the aim of our policy, namely, to enable the natives to meet the impact of our civilization which after the war is bound to be more insistent and difficult'. On the matter of language policy, Matthews asked Love to work with Trudinger on determining the 'balance' in the school between the two languages at issue ${ }^{54}$ Such a 'balance', however, was apparently difficult to achieve, not only on the blackboard, but from the pulpit. Although not (yet) an ordained minister, Trudinger in the early 1940s was preaching to the 'congregation' on one Sunday evening a month in the vernacular. Love, however, was apparently still predominantly preaching in English in July 1942. Trudinger was contemptuous of this. He wrote to Matthews in a thinly veiled criticism of Love: 'we are told the A ustralian A borigine is a born linguist and understands more of our language than we think [but] not one of these [children] speaks English and few if any could understand an English sentence or sequence which does not involve either actions making its meaning clear or words which the native has borrowed from us. ${ }^{55}$ Love's response to this was that the children would not speak English if they were not taught it. Trudinger continued to express his frustration at Sunday morning prayers and services being in English, with only the evening service conducted in Pitjantjatjara. 'Even when we have language fluency [in the vernacular] it is difficult to express some Gospel truths ... but now they are glibly expressed in English ... utterly unintelligible to anyone.' Love's rejoinder that 'they understand a lot more than we think they do' infuriated the young teacher: 'it is torture to sit through ... I cannot attend another one'. ${ }^{56} \mathrm{He}$ was not alone in his agony. One visitor to the mission, a friend of

52. Love to Matthews, 6 October 1943, PCA, ML MSS 1893/4/ 1943.

53. Love to Matthews, 6 October 1943, PCA, ML MSS 1893/ 4/ 1943. These last statements from Love, given his own stubborn resistance to the language policies of Duguid and Trudinger, were al so somewhat disingenuous: see footnote 45.

54. Matthews to Love, 25 October 1943, PCA, ML MSS 1893/ 4/ 1943.

55. Trudinger to Matthews, 17 July 1942, PCA ML MSS 1983/ 1/ 1939-46.

56. Trudinger to Matthews, 1 March 1944, PCA ML MSS 1893/ 1/ 1939-1946. 
Trudinger's, was also mystified by Love's 'obstinate refusal' to conduct morning prayers in Pitjantjatjara: 'How can converts be won if there is no understanding?' 57

Although he never explained himself, it is probable that Love's preaching in English was a deliberate strategy on his part to conduct the sort of 'education in English' that he thought was lacking in the school curriculum. We know that Love was well versed in the local language at least by August $1942 .{ }^{58}$ Wealso know from the evidence of a visitor in 1943 that Love was explaining Scripture in the native tongue in one-toone situations with the Pitjantjatjara. ${ }^{59}$ So it was not from lack of fluency in or knowledge of the local language that Love continued to refuse to use it at service. It is possible that Love may have felt intimidated by Trudinger's much remarked facility with the native language (Matthews wrote of the teacher's 'genius for language' ${ }^{60}$ ) and at least initially was reluctant to preach in Pitjantjatjara. But it is also likely that Love, a determined and stubborn man, continued to adopt a tactic that accorded with his strategy of preparing the 'savage' for the impact of modernity.

The superintendent and the teacher al so clashed (as well as occasionally cooperating) on translation work. Love was reluctant to give the younger man the time he wanted to devote to translation, insisting that Trudinger also assist in more general mission work 'to do justice to the rest of the staff'. ${ }^{61}$ This brought the response from the ambitious young evangelical that Love's attitude 'implied' that translation work was 'on a par with the breaking in of horses, or mending gates, or cleaning out the goat yards'. How could this be as important as 'research into the mysteries of the language and its texts and chants for an effectual understanding of the people's heart and mind? Could not this matter be made definitely clear [to Love]?', mused Trudinger to the Board. ${ }^{62}$ Frustration was clearly building on the mission site. Trudinger was privately contemptuous of Love's efforts at translation: "his "draft" [of the Gospel of St Mark] is a travesty of Pitjantjatjara ... in parts unintel ligible to natives.' While Love was keen to complete the translation, Trudinger was sure that it would take longer than Love thought, telling Matthews it would be preferable to produce something more 'elementary and more immediately useful to the natives' such as a Primer Reader of Bible stories, a small Catechism, and an expanded Hymnal. ${ }^{63}$ Cooperation on the joint translation was clearly difficult. In 1945, Trudinger complained of a 'false impression' given in the Presbyterian Church newspaper, The M essenger, that Love's earlier translation of St Mark was being 'revised' by Love and Trudinger. The teacher asserted that the result of their joint venture was in fact not 'a mere revision' but 'an entirely new translation':

Mr. Love and I have got on amazingly well in our translation but on the understanding, voiced at the outset, that generally he is the authority on the meaning of

57. Wilson to Matthews, 24 March 1944, PCA ML MSS 1893/ 1/ 1939-1946.

58. See the evidence of Pastor FW Albrecht of Hermannsburg: 'Journey North', Burns-Albrecht Collection 1942, AA 662, South Australian Museum Archives, A delaide.

59. Owen 1943.

60. Matthews to SA Education Department, 4June 1943, PCA ML MSS 1893/ 1/ 1939-46.

61. Love to Matthews, 6 October 1943, PCA ML MSS 1893/ 4/ 1943.

62. Trudinger to Matthews, 1 March 1944, PCA ML MSS 1893/ 1/ 1939-46.

63. Trudinger to Matthews, 14 December 1944, PCA ML MSS 1893/ 1/ 1939-46. 
the text to be translated, and I have the better knowledge of the language we are translating into. ${ }^{64}$

He conceded that both men had been 'complementary' to each other in this work, and that 'one without the other could not have produced a translation worthy of being printed'. In the event, one might say that it was perhaps a miracle of sorts that a translation by Love and Trudinger of the Gospel of St Mark into Pitjantjatjara was completed in the year of their Lord $1945 .^{65}$

The Board of Missions was eventually forced to accommodate the strongly expressed views of its superintendent on language policy. A compromise was reached. While the native language was to retain its priority, the Board was now convinced that 'we must do more to prepare these children for the inevitable conflicts with the white population' and directed that English be taught as a 'secondary' language. The Board also suggested that at the English Sunday services, at least a prayer should be offered 'in the vernacular', and that, pending the translated book or books of the New Testament, that translations of 'familiar Bible stories' be made available for 'the natives'. ${ }^{66}$

Yet just as this compromise was being constructed, the controversy was revived by an intervention by the eminence grise of Ernabella, Duguid, towards the end of 1944. Up until then, Duguid had been ominously silent on the matter of the language policy contestations on the mission site. As we have seen, Duguid's privileging of the Indigenous language had a cultural, rather than an evangelical, motive. Nevertheless, Love's comment in a 1944 Ernabella Report that he was 'not satisfied with the progress in the use of English by the native people' was apparently the trigger for Duguid's reaction. ${ }^{67}$ Duguid, after all, was the father of the native language policy and of the Mission itself and it was probably inevitable that he would enter the lists against his superintendent on this issue. Hewent about it in a curiously indirect way. ${ }^{68} \mathrm{He}$ asked the Board of Missions to get answers from Love to four questions. ${ }^{69}$ So Matthews was given the unenviable task of being the intermediary between these former allies in the imagining and establishment of the mission station. Duguid first asked: 'as the natives at Ernabella have not been taught English, what does M r Love wish to convey by writing: "I am not satisfied with the progress in the use of English by the native people"?' Love, in

64. Trudinger to Matthews, 7 July 1945, PCA ML MSS 1893/ 1/ 1939-46. 'Getting on amazingly well' again was probably disingenuous. Roland Boer notes in his perceptive examination of early attempts to translate the Bible into Pitjantjatjara that 'Bob Love and Ronald Trudinger seem to havefought bitterly over most of their timetogether in the 1940s': Boer 2001: 173-179. It should be said, in fairness to Love, that Trudinger's generous acknowledgement to Matthews of Love's part in their collaboration in the translation of Mark into Pitjantjatjara was rarely repeated. Love seems subsequently and unfairly not to have received due credit for his collaborative work in the translation.

65. In fact, this first translation into Pitjantjatjara was not published until four years later, after Love's death.

66. Matthews to Trudinger, 9June 1944, PCA ML MSS 1893/ 1/ 1939-46.

67. Ernabella Mission Report for Year Ending 30 June 1944, PCA ML MSS 1893/ 2/ 1938-46.

68. Most of the 'negotiations' on the mission appear to have been conducted in curiously indirect ways. Most of Love's and Trudinger's claims and counter-claims were lodged with and through a third party, the Board of Missions, specifically Matthews. Negotiation among these Presbyterian missionary colleagues was not a well practised art.

69. Matthews to Love, 25 September 1944, PCA ML MSS 1893/ 4/ 1944. 
response, reiterated his view that "knowledge of English is essential for [the native people's] progress, in meeting the new conditions of life and contacts with white civilization outside the Mission'. Again, he reflected on his experience at Kunmunya where he claimed that children learnt English easily and quickly:

Yet, after 3 years here, I found almost no progress in this direction, on the part of the children. The young men and women have had to acquire their English as they worked with the rest of the staff, after leaving school. There is a fault somewhere. The average intelligence of the children seems to be equal to that of the tropical tribes. Where is, or was, the fault? I was not satisfied that the children had been getting the right opportunity to acquire a working knowledge of English. ${ }^{70}$

Duguid then wanted to know how many children on the mission site could read and write in the native tongue. Love's response, again, was pointed and powerful:

All the children who attend school are gradually learning to do so. This is excellent. To ask two further questions, 'What can they read?' and, 'To whom can they write?' is to reveal the fact that the gate of knowledge remains closed to the schoolchildren of Ernabella, does it not? This is not to disparage the valuable work done. It is to point out that the children have a right to more. ${ }^{71}$

The last two questions related to the use of the native language at services: 'How often is a service conducted wholly in the native tongue?', to which Love answered, curtly: 'One Sunday afternoon per month, by Mr. Trudinger.' And to the query: 'In what way and in what degree are regular services conducted in the native tongue?'. Love explained:

The remaining Sundays, N ew Testament lesson and address in the native tongue, by me; singing of one of Mr. Trudinger's hymns in the native tongue; a reading and psalm in English also. Daily morning prayers: a short prayer in the native tongue, followed by the Lord's Prayer in English. ${ }^{72}$

Love added, in wry acknowledgement of the difficulties in translating work between the superintendent and the teacher: 'the Lord's Prayer in the native tongue will be spoken when $\mathrm{Mr}$. Trudinger and I can arrive at a rendering that will satisfy us both' 73

In a 'review' of five years of school work in June 1945, Trudinger expressed satisfaction that the 'original policy' to 'introduce the Christian Gospel ... as quickly and as thoroughly as possible' without interfering with 'the tribal habit and habitat of life' had been adhered to 'despite considerable opposition'. The teacher directed another pointed reference at his superintendent's attitudes when he listed the achievements of the school over the period: over 200 attendees, 80 with some literacy in their language, no deaths or serious illnesses: these results were, he claimed defensively, 'far from disappointing'. He anticipated that by 1947 'every family would have a copy of a Gospel and a member able to read it'. He defended the use of the native tongue as the medium for conversion:

70. Love to Matthews, 2 November 1944, PCA, ML MSS 1893/ 4/ 1944.
71. Love to Matthews, 2 November 1944, PCA, ML MSS 1893/ 4/ 1944.
72. Love to Matthews, 2 November 1944, PCA, ML MSS 1893/ 4/ 1944.
73. Love to Matthews, 2 November 1944, PCA, ML MSS 1893/ 4/ 1944. 
whatever the advisability of English instruction in other realms, the spiritual, being a deep, sacred matter of the inner mind and soul, is only apprehended through the native's habitual thought medium. There is no Divine premium on English. ${ }^{74}$

To the young evangelical, the primary purpose of the education of 'natives' was to bring forth 'the first fruits of the Gospel teaching here'. It was not 'the making of semicivilized sophisticates'. Despite the compromise of 1944, the battle lines on the mission site remained drawn.

In the context of discussions Matthews had been having with Love on the prospects for employment of the young people at the mission, the Board wanted to know in 1944 what Love's 'model' was for the future of Ernabella. In answer, Love penned his 'Policy of Ernabella'. ${ }^{75}$ Prefacing his remarks with the observation we have already noted that the missionary had a 'special duty' to save the race 'from extinction', he put forward a complicated vision that held two seemingly incompatible goals together in what he hoped was a sort of creative tension. He wished to retain the traditional nomadic life for the native at Ernabella: 'All people at Ernabella are nomadic. N onestay here for a long time. Let them continue to be nomadic.' He wished to continue the feeding regime extant at Ernabella; rations to the needy, food and goods exchanged for scal ps, reliance on bush tucker when available, and mission assistance during drought and famine. At the mission and in the hills of the Reserve, they would be protected from the corrosive effects of white civilisation. As regards employment, he did not think that Ernabella would be able to employ permanently more than a comparatively small proportion of the people:

They do not want to be permanently employed. Let them go off to the bush again, and give them opportunities to take their share of the work done for the good of each. My present system is 3 months work, then off bush. ${ }^{76}$

The other side of Love's vision, balancing the idealism of his 'nomadic' and sheltered future for the A borigines of the Musgrave Ranges, was a tough-minded view that the Indigenous people there had to develop the means to withstand what Love saw as the potentially fatal impacts of the encroaching European civilisation. One means lay in learning English. A nother lay in making sufficient use of their land in order to 'earn the right' to retain it against what Love knew to be a voracious and ruthless civilisation. It was in this context that Love came to believe that the development of a sheep industry was the appropriate economic model for the mission, but al ways subordinate to, while

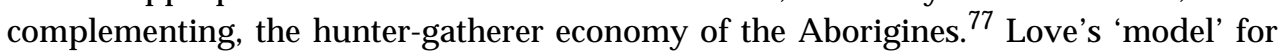

74. Report on the Ernabella Mission School, June 1945, PCA, ML MSS 1893/ 2/ 1938-45.

75. Love, The Policy of Ernabella 1944, PCA, ML MSS 1893/ 2/ 1938-45.

76. Love, The Policy of Ernabella 1944, PCA, ML MSS 1893/ 2/ 1938-45.

77. Love eventually advised the Board that Ernabella should carry about 5000 sheep. He al so thought blocks between Ernabella and the Great Australian Reserve to its west should be stocked and worked from themission station, solely for the 'future living of A borigines', with profits retained within the mission for its improvement. Love encouraged the Board to continue to make every endeavour 'to settle this question of the three blocks - and to have them held in perpetuity for theA borigines'. He saw the sheep industry as being 'the salvation of the people from an industrial point of view': Love to Matthews, 14 February 1946, PCA, ML MSS 1893/ 4/ 1946. 
Ernabella was for the retention of the traditional economy only as far as possible and only for as long as possible. He had al ways conceded that the impact of white civilisation was inevitable and that 'the black man' would need to adapt to that impact if he was to survive. 78

Survival was now, however, a question for Love himself. The contradictions and complexities within the discourses on A borigines that flowed between the metropolitan centres and the isolated mission station and its different missionaries were beginning to take their toll. A moderate-evangelical divide seemed to have developed at Ernabella mission, and what had in reality been a power struggle between Love and Trudinger, al most from the first, had come to a head. In this struggle, the schoolteacher's superior command of the local language had been a considerable weapon. By 1945, the evangelicals were strengthening their forces behind Trudinger. Despite his relative youth, the Board had positioned him as the successor to Love and even the exemplary missionary himself, tired and disillusioned, seemed so resigned to the fact that he had suggested the teacher to the Board as 'the man for the position'. ${ }^{79}$

Matters now quickly resolved themselves. Duguid had not been satisfied at Love's responses to his 'four questions'. The Adelaide Committee, charged by the church with an overview role on the mission, and chaired by Duguid, had asked to meet with the Board, and Matthews and two other Board members had flown to Adelaide. Matthews communicated the Committee's concerns to Love. The most sensitive issue raised was the language policy. Concerns had again been raised about the use of English at services. The Board had even been asked if it was prepared to order the discontinuance of daily services in English. It refused to do so. However, Matthews indicated that the Board had re-affirmed its policy that as the missionaries at Ernabella became more proficient in the native language the daily services should be increasingly in the native language. He explained it awkwardly to Love in these terms: 'That is how the Board interpreted its discussions with you during your furlough. ${ }^{80}$ Love immediately levelled his weapons at the Committee and accused it of having gone outside its 'proper function of auxiliary to the Board of Missions'. Hethen proceeded to answer the queries put to him, and elaborated, again, on the matter of the use of English at services:

Here I think we come to the chief difference between me and some others. We're back where we were last year when I met the Board ... I repeat: The people must have the Gospel in their own tongue. They are getting it. English is indispensable. Without English the school would be futile. I repeat: this is not to decry good work done, but to insist on its inadequacy. ${ }^{81}$

Love now fired off a last plea to the Board of Missions: 'N ow, brethren, will you decide by whose experience, knowledge and judgement you shall be guided in the management of Ernabella?' ${ }^{2}$ 'Translation' by negotiation was an exhausting business.

\footnotetext{
78. Love to Matthews, 14 February 1946, PCA, ML MSS 1893/ 4/ 1946.

79. Matthews to Wright, 3 December 1945, PCA, ML MSS 1893/4/ 1945. In the event, Rev. C Wright succeeded Love in an acting capacity while Trudinger completed his divinity studies. After his ordination, he became superintendent of Ernabella Mission in 1949.

80. Matthews to Love, 8 March 1945, PCA, ML MSS 1893/ 4/ 1945.

81. Love to Matthews, 28 March 1945, PCA, ML MSS 1893/ 4/ 1945.
} 
Love's attempts at negotiating a bi-lingual policy had largely failed, it seemed to him, and he was resorting at the last to relying on his reputation as the exemplary missionary and on seniority. But in fact he had had enough. Soon after penning these words, Love decided to retire from the mission field. While initially citing ill-health as a reason for resignation, Love eventually acknowledged, in response to prompting from Matthews, that 'the immediate cause' was his 'inability to win the complete confidence and full cooperation of two men'. ${ }^{83}$ The two men were not named but we may reasonably assume that they were Charles Duguid and RM Trudinger. There was a complex coterie of reasons for the disagreements between Love and the 'two men', some of which have been noted above. Duguid's role in the Adelaide Committee, along with his status as the founder of the Mission, put him in a potentially adversarial position vis-à-vis Love. Duguid had needed Love's prestige within the church to enable him to establish the mission but once the enterprise was operating, the partnership had begun to fracture under pressure. Given Duguid's very combative nature and Love's inclination to do things his way as superintendent, this situation was bound to lead to conflict. ${ }^{84}$

With Trudinger, it was another knot of reasons. The younger man had arrived at the mission before Love, and had picked up the language, as we have seen, with greater facility than Love while developing the school. Duguid, the Board of Missions and many in missionary circles saw the work of the school and its teacher as the most important achievement of the Mission. At times, it was almost characterised as its only achievement. It is probable that Trudinger, consciously or unconsciously, conveyed this impression to Love. ${ }^{85}$ Love's dream had been to build a 'Kunmunya in the desert': to Trudinger, and others, Ernabella was unique. Add to this a generation gap felt keenly by the older man, the somewhat arrogant reluctance on Trudinger's part to accept Love's leadership fully and it was inevitable that points of conflict with Love emerged. It also appears that Love attempted to advise Trudinger to exercise more discretion in his dealings with Aboriginal females and that this advice was brushed aside, which irritated and concerned the older and more experienced missionary. ${ }^{86}$ Later events confirmed Love's wisdom in this matter. Despite the fraught relationship between the two, they cooperated occasionally, working together on the translation of the Bible, the design of the new school, and there was the odd pleasantry: Love, having published in 0 ceania himself and knowing AP Elkin the editor, assisted Trudinger in getting an article published in the al ready prestigious anthropological journal in 1943, and later lent the young man some texts on Hebrew and Greek when he went to Melbourne to study for the ministry. ${ }^{87}$ Finally then, differences both personal and ideological with Duguid and Trudinger, par-

82. Love to Matthews, 28 March 1945, PCA, ML MSS 1893/ 4/ 1945.

83. Love to Matthews, 10 August, 1945, PCA, ML MSS 1893/ 4/ 1945.

84. AP Elkin, the well-known anthropologist, who had had dealings with Love in Western Australia, had warned Duguid in 1940 that Lovedisliked interferencein his missions: Elkin to Duguid, 27 December 1940, Papers of Charles Duguid. But (it should be conceded) Duguid, direct, dogmatic and determined (Dr Do-Good, some said) was not an easy man to get on with!

85. Perhaps it was this sort of attitude that prompted Love, in May 1944, to note regarding Trudinger: 'You will see that he is going from strength to strength in his wilful and selfish way': Love to Matthews, 31 May 1944, PCA, ML MSS 1893/4/ 1944.

86. Matthews to Trudinger, 9June 1944, PCA, ML MSS 1893/ 1/ 1939-46.

87. Trudinger 1943; Trudinger to Matthews, 5 September 1944, PCA, ML MSS 1893/ 1/ 1939-46. 
ticularly over language policy, appear to have added just sufficient negative weight to have broken the fragile working relationship between the three men. Love notified Matthews and Duguid that he would makethis term his last. Hecal culated that he had done 'about 30 years of work for the A borigines'. The time had come 'to hand on the burden to another man'. Hewas giving long notice so 'the work of Ernabella may go on without any break in continuity'. ${ }^{88} \mathrm{H}$ is tour of duty was done. 89

The 'work of Ernabella' would go on, attempting to find ways of achieving the difficult and precarious balance Love as superintendent had been seeking, between protecting the Aborigines from the usurping white world while preparing them for entry into it. The sheep industry would come and go. The mission itself would also go, under policies of autonomy and self-determination for the Indigenous people. Land rights would come in 1981. The Anangu Pitjantjatjara Yankunytjatjara Lands would return to their original custodians. With this event came optimism and hope. But this, too, was to go, or at least fade, amid worsening social and economic problems. Despair and hopelessness came to Ernabella - Pukatja as it was now also called - or at least to white commentators watching from a distance. Through it all, the delicate work of 'translation', of finding a bal ance between the dominant national language and the local language has persisted, oscillating to some extent between the extremes of English-only and vernacular-only. When official policies move towards one or other end of the spectrum, adherents of the opposite side raise voices in alarm. A bilingual policy of sorts, of which Love would probably have approved, currently holds sway on the Lands. English is the primary language of instruction in the schools, but the Indigenous language and culture can be, and is at Ernabella, included in the curriculum. ${ }^{90}$ Pitjantjatjara as a language has survived, especially in emerging genres of reportage and advocacy. ${ }^{91}$ It cannot yet claim to have generated a genre of literature. However, one of the world's pre-eminent texts, the Bible, through a complex process of negotiations between English and Indigenous translators, continues to seek dynamic equivalence in the Pitjantjatjara language. ${ }^{92}$ This process was initiated at Ernabella by RM Trudinger and by JRB Love himself. Perhaps both men, if they could survey the aftermath of their originary negotiation of the work of 'translation' at Ernabella, may feel more vindicated than aggrieved. And yet does Charles Duguid, who was buried at his bel oved Ernabella in 1986, now rest easily in his grave?

88. Love to Matthews 25 A pril 1945, PCA, ML MSS 1893/ 4/ 1945.

89. Love retired from the mission in 1946 and was elected Moderator of the General A ssembly of the Presbyterian Church of South Austral ia, a tribute to his service to the church and to Aboriginal people. However, he died of kidney disease early in 1947. Trudinger became superintendent of Ernabella in 1949 and continued the work of translating parts of the Bible into the Pitjantjatjara language with the assistance of A boriginal co-translators.

Report of the Select Committee 2004: 45.

91. Goddard 1990.

92. See, for example, the Pitjantjatjara Shorter Bible 2006. The reference to dynamic equivalence recalls the part played in biblical translation, in Australia as well as worldwide, by the work and methodology of Eugene Nida. 


\section{References}

\section{Primary sources}

Papers of Pastor FW Albrecht, Burns-Albrecht Collection, AA662, South Australian Museum Archives, Adelaide.

Papers of Charles Duguid, MS 5068, Series 1, general correspondence, 1918-1974, National Library of Australia.

Papers of John Flynn, MS 3288, N ational Library of A ustralia.

Papers of JRB Love, PRG 214, State Library of South A ustralia, Mortlock Collection.

- Series 21, PRG 214, Diary of a Visit to Ernabella to establish a Presbyterian Mission, 24 May-24 October 1937, 102pp.

Presbyterian Church of Australia, ML MSS 1893, Mitchell Library, Sydney.

Report of the Select Committee on Pitjantjatjara Land Rights, Parliament of South Australia, 2 June 2004.

State Records of South Australia, A boriginal Affairs Department, A boriginal Protection Board, Correspondence Files, GRG 52/ 1, A delaide.

\section{Secondary sources}

Biskup, Peter 1973, N ot slaves not citizens: the A boriginal Problem in W estern A ustralia, 1898-1954, University of Queensland Press, St Lucia.

Boer, Roland 2001, Last stop before A ntarctica: the Bible and postcolonialism in A ustralia, Sheffield A cademic Press, Sheffield.

Broome, Richard 1994, A boriginal A ustralians: black responses to white dominance 17881994, 2nd ed, Allen \& Unwin, St Leonards, New South Wales.

Carey, Hilary M 1996, Believing in A ustralia: a cultural history of religions, Allen \& Unwin, St Leonards, New South Wales.

Coates, Ken S 2004, A gl obal history of indigenous peoples: struggle and survival, Palgrave Macmillan, New York.

Comaroff, Jean and John L Comaroff 1991, Of revelation and revolution: Christianity, colonialism and consciousness in South A frica, vol 1, University of Chicago Press, Chicago.

Duguid, Charles 1936, 'The Australian A borigines', statement included in Presbyterian Church of A ustralia, Minutes of Proceedings of the General Assembly of the Presbyterian Church of Australia, September 1936, Sydney.

— 1972, D octor and the A borigines, Rigby, Adelaide.

— 1978, 'Tribal nomadic people', A ustralasian N urses Journal 7(12): 27.

Eco, Umberto 2003, M ouse or rat? Translation as negotiation, Weidenfeld \& Nicolson, London.

Gale, Mary-Anne 1992, 'Publish or perish?: Observations on the reasons for writing in A boriginal languages', A ustralian A boriginal Studies 2: 42-48.

Goddard, Cliff 1990, 'Emergent genres of reportage and advocacy in the Pitjantjatjara print media', A ustralian A boriginal Studies 2: 27-47.

Harker, RK and KR McConnochie 1985, Education as cultural artifact: studies in M aori and A boriginal education, Dunmore Press, Palmerston N orth. 
Harris, John 1990, O ne Blood: 200 years of A boriginal encounter with Christianity: a story of hope, Albatross, Sydney.

Hilliard, Winifred 1976, The people in between: the Pitjantjatjara of Ernabella, Seal Books, Adelaide.

Love, JRB 1922, 0 ur A ustralian blacks, Brown, Prior Co Pty Ltd, M elbourne.

- 1936, Stone-age bushmen of today: life and adventure among a tribe of savages in northwestern A ustralia, Blackie and Son Ltd, London and Glasgow.

McKay, Graham 1996, The land still speaks: review of A boriginal and Torres Strait Islander language maintenance and devel opment needs and activities, AGPS, Canberra.

Owen, Eric 1943, A visitor's diary: Ernabella Patrol 1943, Presbyterian Church of Australia, Board of Missions, Melbourne.

Phillipson, R 1992, Linguistic Imperialism, Oxford University Press, Oxford.

Pitjantjatjara Bible Translation Project 2006, Pitjantjatjara Shorter Bible, Bible Society in Australia, Sydney.

Pratt, Mary Louise 1992, Imperial eyes: travel writing and transculturation, Routledge, London.

Radford, Robyn 1992, 'A spects of the social history of Hermannsburg' in The heritage of $\mathrm{N}$ amatjira: the watercolourists of Central A ustralia, Jane Hardy, JVS M egaw and M Ruth Megaw (eds), William Heinemann A ustralia, Melbourne: 63-96.

Stanley, Brian (ed) 2001, Christian missions and the Enlightenment, Curzon Press, Richmond.

Trudinger, David 2004, 'Converting salvation: Protestant missionaries in Central A ustralia, 1930s-1940s', PhD thesis, Australian N ational University, Canberra.

Trudinger Ronald M 1943, 'Grammar of the Pitjantjatjara dialect, Central A ustralia', 0 ceania 13(3): 205-223.

Young, Robert JC 2001, Postcolonialism: an historical introduction, Blackwell, Oxford. 